\title{
KASSIM AHMAD PELOPOR INKAR SUNNAH DI MALAYSIA
}

\author{
Darussalam $^{1}$, Neng Lutfi Maspupah ${ }^{2}$ \\ ${ }^{1} J$ urusan Ilmu Hadis Pascasarjana, UIN Sunan Gunung Djati, Jl. A.H. Nasution 105 \\ Bandung, Indonesia \\ ${ }^{2}$ Jurusan Pendidikan Agama Islam Pascasarjana, UIN Sunan Gunung Djati, Jl. A.H. \\ Nasution 105 Bandung, Indonesia \\ (Drrslmsalam@gmail.com; neglutfimaspupah@student.uinsgd.ac.id)
}

\begin{abstract}
Abstrak
Munculnya Ingkar Sunnah sebenarnya bukanlah hal baru pada zaman modern ini, hal ini telah ada sejak akhir abad pertama namun tidak bertahan lama, seiring arus modernisasi, kecenderungan berfikir rasional dikalangan para mujaddid, dan bias dari pemikiran orientalis, perkembangannya hingga masuk pada negara muslim di Asia Tenggara yaitu Indonesia dan Malaysia. Pemahaman penolakan terhadap Hadis Nabi sebagai sumber Hukum Islam setelah Al-Qur'an turut mempengaruhi pemikiran para tokoh intelektual di Indonesia seperti Nazwar Syamsu dan Kassim Ahmad di Malaysia. Kasiim Ahmad seorang Islamolog Ketua Partai Komunis. Dia rajin menulis dan mengeluarkan berbagai statemen yang melecehkan sirah Nabi dan Sunnah beliau. Dia mempunyai sebuah buku berjudul "Hadits Penilaian Semula," yang kemudian dilarang terbit oleh Pemerintah Kerajaan Malaysia karena banyak menuai kritik dan hujatan dari kaum muslimin dan para ulama di sana. Dalam bukunya, dia mengatakan bahwa umat Islam tidak perlu menerapkan Sunnah dalam penerapan ajaran agamanya.
\end{abstract}

Kata kunci: Kassim Ahmad, Inkar Sunnah, Malaysia

\begin{abstract}
The emergence of Ingkar Sunnah is actually not new in this modern era, it has existed since the end of the first century but did not last long, along with the current of modernization, the tendency of rational thinking among the mujaddid, and the bias of Orientalist thought, its development to enter the Muslim countries in Asia Southeast namely Indonesia and Malaysia. Understanding the rejection of the Hadith of the Prophet as a source of Islamic Law after the Qur'an has influenced the thinking of intellectual figures in Indonesia such as Nazwar Syamsu and Kassim Ahmad in Malaysia. Kasiim Ahmad is an Islamologist Chair of the Communist Party. He diligently wrote and issued various statements that insulted the sirah of the Prophet and his Sunnah. He has a book called "The First Assessment Hadith," which was later banned by the Government of the Kingdom of Malaysia because there was much criticism and blasphemy from the Muslims and the scholars there. In his book, he said that Muslims do not need to apply the Sunnah in the application of their religious teachings.
\end{abstract}

Keyword: Kasim Ahmad, Inkar Sunnah, Malaysia 


\section{PENDAHULUAN}

Jumhur kaum muslimin mengakui hadis sebagai sumber hukum kedua setelah al Qur'ān. Keyakinan ini bukan hanya didasarkan atas dalil-dalil "naqli" yang berupa ayat dan hadis saja, tetapi secara logis terbukti bahwa segala ucapan, perbuatan, dan ketatapanm Rasul SAW merupakan implementasi dari ajaran al-Qur'ān. ${ }^{1}$ Dengan demikian, kedudukan hadis dalam merumuskan tatanan kehidupan umat Islam seharusnya tidak diragukan lagi oleh para pemeluknya. Asy-Syaukani, sebagaimana dikutip oleh Muhammad Thahir Hakim mengatakan bahwa sesungguhnya kekuatan hadis/sunnah dalam pembentukan hukum Islam merupakan kebutuhan pokok keagamaan dan tidak ada kebenaran bagi orang yang menginkarinya. ${ }^{2}$

Namun sejarah mencatat sisi negatif perjalanan umat ini dengan masih adanya sekelompok orang yang mengabaikan, meragukan, bahkan mengingkari eksistensi hadis. Sejarah mencatat nama Imam Asy-Syafi'i (w. 204H) yang telah memainkan perannya dalam membela al-hadis sehingga beliau mendapat julukan "nāshir alsunnah". ${ }^{3}$

Dewasa ini, sikap orang Islam terhadap hadispun kian beragam. Di berbagai negara, seperti di India, Pakistan, Mesir, bahkan di Malaysia muncul gerakan anti hadis. Di India dan Pakistan gerakan ini muncul pada tahun 1906M dengan nama Jami'iyah Ahli Qur'an. Gerakan ini di ketuai oleh Abdullah Chakrawali dan Khawaja Ahmad Din. Dalam propagandanya gerakan ini mengklaim bahwa al-Qur'ān sudah cukup untuk menjelaskan semua perkara agama dan mereka menolak hadis secara keseluruhan sebagai dasar tasyri'. Bahkan, kelompok ini membuat aturan shalat sendiri yang berbeda dengan aturan shalat yang ada. Mereka mengurangi jumlah rakaat-rakaat shalat serta membuang bacaan-bacaan shalat yang menurut mereka tidak ada dalilnya dalam al-Qur'ān. Propaganda anti hadis ini belakangan diteruskan oleh Ghulam Ahmad Parwez dan Sayyid Rafiuddin Multan. ${ }^{4}$ Akan tetapi gerakan ini mendapat kecaman dari para ulama seperti, Muhammad Ismail as-Salafi, Abul 'Ala al-Maududi dan Muhammad Ayyub Dahlawi.

Gerakan anti hadis juga muncul di Mesir. Hal ini terlihat dalam tulisan Muhammad Taufiq Shidqi yang dimuat dalam majalah al-Manar Kairo. Dalam artikel tersebut beliau mengatakan, bahwa perilaku Nabi Muhammad SAW tidak dimaksudkan untuk ditiru secara keseluruhan oleh umat Islam. Umat Islam semestinya berpegang cukup pada al-Qur'ān saja. Pandangan ini ditentang keras oleh para ulama Mesir, seperti Syaikh Ahmad Manshur al-Baz, Syaikh Thaha al- Bishri,

\footnotetext{
${ }^{1}$ Utang Ranuwijaya, Ilmu Hadis (Jakarta: Gaya Media Pratama, 1996). Hal. 19

${ }^{2}$ Muhammad Thahir Hakim, As-Sunnah Fi Muwajahah Al-Abathil (Jakarta: Granada, 1984). Hal. 21

${ }^{3}$ Musthafa Al-Siba 'i, Al-Sunnah Wa Makanatuhu Fi Tasyri' Al-Islami (Beirut: al-Maktabah al-Islami, 1978). Hal. 148

${ }^{4}$ Abdurrahman Azam, Keagungan Nabi Muhammad SAW: Kepahlawanan Dan Keindahan Kehidupan Rasulullah (Jakarta: CV Pedoman Ilmu Jaya, 1982). Hal. 28-29
} 
dan Syaikh Shalih al-Yafi'i. Selain Shidqi, cendikiawan liberal Mesir seperti Ahmad Amin, Muhammad Husain Haykal dan Taha Husain juga mempersoalkan status hadis sebagai sumber hukum Islam. Mahmud Abu Rayyah, cendikiawan liberal Mesir lainnya, dalam karya-karyanya juga menolak otentisitas, otoritas dan integritas ('adalah) sahabat sebagai transmitter hadis. Sama dengan kelompok inkar sunnah lainnya, pendapat Abu Rayyah ini mendapat kecaman dan kritikan tajam dari intelektual pencinta hadis seperti Muhammad Abu Shuhbah, Muhammad Abu Zahrah, Muhammad Ajjaj al-Khatib, Musthafa as-Siba'i, dan tokoh-tokoh hadis lainnya. ${ }^{5}$

Gerakan anti hadis di Malaysia, muncul pada tahun 1980-an yang dipelopori oleh Kassim Ahmad. Pemikiran Inkar Sunnah Kassim Ahmad dapat dilihat dalam bukunya "Hadis Satu Penilaian Semula" (HSPS). Buku kontroversial ini berasal dari ceramah-ceramah beliau pada jurusan Antropologi dan Sosiologi Universitas Kebangsaan Malaysia (UKM). Buku setebal 131 halaman ditulis dalam bahasa Melayu diterbitkan pertama kalinya oleh Media Intelek SDN BHD, Petaling Jaya Selangor, Malaysia tahun 1986. Dan hanya mengalami cetak ulang kedua karena tahun-tahun berikutnya telah dilarang peredarannya oleh pemerintah kerajaan Malaysia. Pertanyaannya adalah siapa Kassim Ahmad, bagaimana pemikiran inkar sunnah Kassim Ahmad dan kenapa pemikiran Kassim Ahmad mendapat respons luas dalam masyarakat? Pertanyaan-pertanyaan inilah yang ingin dijawab dalam makalah ini.

\section{PEMBAHASAN}

\section{Biografi Kassim Ahmad dan Riwayat Pendidikannya}

Kassim Ahmad merupakan anak pertama dari tiga bersaudara. Beliau dilahirkan pada tanggal 9 September 1933 di Bukit Pinang Kota Setar Kedah Malaysia dengan nama Osman, Namun ketika masih kecil sering sakit-sakitan, maka namanya diubah menjadi Kassim. Ayahnya bernama Ahmad bin Ishak berprofesi sebagai guru agama Islam dan ibunya adalah seorang ibu rumah tangga bernama Ummi Kalthom bte $\mathrm{Hj}$ Ahmad. Orang tua dari pihak bapaknya adalah generasi keempat keturunan Minangkabau, Sumatera Barat. Sementara dari pihak ibunya berasal dari Thai Melayu Provinsi Pattani. Datuk lelakinya bernama Lebai Ishak bin Lebai Teh, seorang guru agama Islam dan juga seorang petani yang tinggal di Seberang Perai Pulau Malaysia. ${ }^{6}$

Ahmad bin Ishak kawin dengan anak bungsu seorang petani dari Kedah. Buah dari perkawinan ini kemudian lahirlah Kassim bin Ahmad. Semasa kecilnya, Kassim Ahmad tinggal dengan selalu berpindah-pindah mengikuti tugas bapaknya yang berprofesi sebagai guru agama di berbagai tempat. Sebelum menetap di Bukit Pinang,

\footnotetext{
${ }^{5}$ Ali Mustafa Yaqub, Kritik Hadis (Jakarta: Pustaka Firdaus, 1995). Hal. 48-49

${ }^{6}$ Kassim Ahmad Abu Zaky Fadhal, Sidang Roh, Mengajak Kita Memperhitungkan Kembali Hidup Kita (Kuala Lumpur: Dewan Bahasa, 1966). Hal. 68
} 
Ahmad bin Ishak, ayah Kasim Ahmad, tinggal di beberapa bandar kecil di wilayah Kedah Malaysia.

Rihlah intelektual dimulai dengan memasuki sekolah Melayu di Bandar Baru dari tahun 1939-1946. Setelah tamat dari sekolah tersebut dia melanjutkan studinya ke Maktab Sulthan Abdul Hamid di Alor Setar Kedah pada tahun 1947-1954 dan lulus dengan predikat "Post School Certificate". Kassim Ahmad, dikenal sebagai anak genius dan rajin. Hal ini terbukti dari prestasi akademis yang selalu dia peroleh semenjak dari bangku sekolah rendah sampai perguruan tinggi. Sewaktu di sekolah rendah, Kasim kecil selalu memperoleh pujian dari para guru-gurunya. Begitu juga sewaktu di sekolah menengah dan karena kepintaran dan kerajinannya tersebut dia diberi jabatan ketua pelajar (OSIS) di sekolahnya. Jenjang pendidikan tinggi, dia tempuh dengan memasuki Universitas Malaya Singapura dan selesai pada tahun 1959 dengan meraih gelar Bachelor of Art (BA) dan kemudian melanjutkan ke Universitas Malaya di Kuala Lumpur dan selesai pada tahun 1961 dengan meraih gelar Master of Art (MA). ${ }^{7}$ Pada tahun 1960, Kasim Ahmad menikah dengan Shariffah Fawziah binti Yussoff Syed Alsagoff, putri seorang polisi negeri Selangor. Dalam pernikahan tersebut Kasim Ahmad dikurniai dua orang putri dan satu orang putra. ${ }^{8}$

Setelah menyelesaikan studinya, Kassim Ahmad bekerja sebagai pegawai penyelidik di Dewan Bahasa dan Pustaka Kuala Lumpur. Dengan bantuan, JC Bottoms, dosen University Malaya Singapura, Kassim Ahmad mendapat kesempatan untuk mengajar bahasa dan sastera Melayu di School of Oriental and African Studies (SOAS), University London, pada tahun 1962 hingga tahun 1966. Pulang ke Malaysia, beliau mengajar di sebuah sekolah menengah di Pulau Pinang. Karena dia seorang yang berjiwa bebas dan tidak terlalu suka mengikut undang-undang yang menekan, Kassim Ahmad dikeluarkan dari pegawai kerajaan pada tahun 1969 dengan alasan menyebarkan risalah partai kepada anak muridnya. Kemudian, Kassim Ahmad menjadi penulis bebas, wartawan dan guru bebas hingga sekarang.

Kassim Ahmad adalah intelektual multi talenta. Dia dikenal sebagai penyair, budayawan sekaligus politikus handal. Kassim Ahmad memulai pekerjaan pada waktu sangat pagi sekali, yakni pukul 3.00 (jam 2.00 WIB/ dinihari) dan tidur pukul 9.30 malam setelah bekerja selama hampir 15 jam. Dan tidak jarang beliau bekerja tujuh hari dalam satu minggu. Dengan jadwalnya yang super sibuk, dia selalu menyempatkan untuk berdiskusi dengan keluarga dan juga dengan kerabatnya dalam berbagai hal, terutama tentang ajaran al-Qur'ān. Dia mengundang teman-temannya makan siang atau makan malam untuk berdiskusi tentang berbagai macam issu. Sampai saat ini kebiasaan tersebut masih tetap dia lakukan, tidak terkecuali dengan lima orang cucunya yang tinggal di Penang.

Kecintaannya kepada sastera dan tulis menulis telah membawanya menjadi seorang penyair dan penulis terkenal. Atas prestasi ini, Kassim Ahmad dianugerahi

${ }^{7}$ Kassim Ahmad, Biodata Kassim Ahmad (Kuala Lumpur: Bernama Library Information Servis, 1986). Hal. 1

${ }^{8}$ Ahmad, Biodata Kassim Ahmad. 
ijazah kehormatan Doktor Persuratan oleh Universiti Kebangsaan Malaysia pada tahun 1985 dan Anugerah Penyair Gabungan Penulis-penulis Nasional (GAPENA) pada tahun 1987.

Minat Kassim dalam bidang politik dan falsafah memperkenalkannya kepada gerakan politik-falsafah La Rouche di Amerika Serikat, Partai Baath dan Saddam Hussein di Iraq, dan sarjana Mesir Dr. Rashad Khalifa yang bermukim di Tucson, Arizona, Amerika Serikat (USA). Minatnya yang kuat dalam bidang politik telah menjadikannya seorang politikus radikal yang kemudian memegang jabatan pengurus kebangsaan Partai Sosialis Rakyat Malaysia (PSRM) yang akhirnya mengantarkannya sebagai tahanan politik selama hampir lima tahun. Beliau dibebaskan pada tanggal 30 Juli 1981 semasa pemerintahan Dr. Mahathir Muhammad dan Datuk Musa Hitam Setelah keluar dari tahanan tahun 1986, Kassim Ahmad mengejutkan banyak pihak dengan tindakannya untuk masuk UMNO, yang mereka lihat sebagai bentuk "pengkhianatan" terhadap ideologi sosialisme dan PSRM yang selama ini beliau perjuangkan. Pada partai yang baru ini, beliau mencoba membawa reformasi, akan tetapi gagal. Dengan demikian semenjak tahun 1992, beliau meninggalkan

panggung politik aktif.

\section{Pemikiran Inkar Sunnah Kassim Ahmad}

Seperti sejarawan pada umumnya, Kassim Ahmad menggunakan pendekatan historis-sosiologis untuk menolak eksistensi hadis sebagai sumber hukum Islam. Asumsi dasar yang dipakai adalah bahwa fenomena sosial yang hadir di alam ini tidak terlepas dari kondisi dan situasi sosial yang melingkupinya. Pendekatan model ini menafikan adanya realitas non empiris yang ikut berperan dalam sebuah fenomena sosial.

Kassim Ahmad mengatakan, bahwa pada masa pemerintahan Mu'awiyah (661-680M) hingga pada saat hadis dibukukan secara resmi pada akhir abad kedua hijrah, pemalsuan hadis terjadi secara leluasa. Pada waktu itu, hadis dijadikan bahan cerita dan alat bagi kelompokkelompok politik dan teologi untuk menegakkan pendapat mereka masing-masing, sehingga sedikit sekali jumlah hadis yang boleh dianggap sebagai pikiran-pikiran dari Nabi Muhammad SAW. Untuk mencegah maraknya pemalsuan hadis dan membendung perpecahan di kalangan umat Islam, maka timbullah gerakan untuk menetapkan sumber perundangan dalam Islam, sekaligus juga untuk mengangkat posisi hadis. Inilah sebab sosial yang akhirnya memunculkan tokoh besar perundangan Islam, yakni Imam Syafi'i (w.204/820M). Dan beliau ini pulalah yang telah menetapkan sumber-sumber perundangan Islam, yaitu; al-Qur'ān, al-hadis, ijma' dan qiyas. Inilah dilema yang terbesar yang dihadapi oleh umat Islam dewasa ini. ${ }^{9}$ Sebaliknya, Kassim Ahmad mengatakan bahwa ketika

\footnotetext{
${ }^{9}$ Kassim Ahmad, Hadis Satu Penilaian Semula (Kuala Lumpur: Media Intelek, 1986). Hal.
} 
Nabi Muhammad SAW wafat, beliau hanya meninggalkan al-Qur'ān sebagai warisan dan tidak ada yang lain, termasuk hadis. Hal ini secara eksplisit dijelaskan Allah SWT berkali-kali dalam al-Qur'ān, bahwa tugas rasul hanyalah menyampaikan perutusan. $^{10}$

Ketika terjadi pertentangan antara aliran pikiran (ahl ar-ra'yu) dengan aliran sunnah (ahl al-sunnah) dan pada akhirnya kemenangan dan penerimaan teori perundangan al-Syafi'i, maka hadis diberi tempat yang utama bersama-sama alQur'ān. Dengan demikian, penggunaan pikiran kreatif atau ijtihad, tidak diperbolehkan lagi. Inilah yang kemudian dikenal dengan ungkapan"penutupan pintu ijtihad" dan permulaan taqlid yang berlanjut sampai awal abad kedua puluh. ${ }^{11}$ Dan pada akhirnya telah menyebabkan negara-negara Islam menjadi mundur dan terzalimi di dunia. ${ }^{12}$

Kassim Ahmad mengatakan, bahwa apa yang disebut oleh ahl alhadis dengan enam kitab "shahih" yang telah dikumpul oleh Bukhari, Muslim, Tirmizi, Abu Daud, Ibn Majah dan al-Nasa'i tidak ada pada waktu Nabi wafat, sebagaimana halnya alQur'ān. Kitab-kitab tersebut baru ada sekitar 210 sampai 230 tahun sesudah Nabi Muhammad wafat. Bukankah ini bukti yang menunjukkan bahwa hadis satu perkembangan baru yang tidak diajarkan oleh Nabi Muhammad SAW. Sebaliknya, andaikata benar apa yang dikatakan oleh ahl al hadis, bahwa hadis-hadis telah dicatat pada waktu Nabi masih hidup, dihafal dan ditransformasikan dari satu generasi ke generasi berikutnya hingga hadis dibukukan secara resmi pada abad kedua hijrah. Pertanyaan kita adalah mengapa pengumpulan hadis baru dilakukan pada abad kedua hijriyah dan tidak pada masa lebih awal, umpamanya pada masa pemerintahan khalifah-khalifah alRasyidun ${ }^{13}$

Kassim Ahmad menolak penafsiran ayat-ayat al-Qur'ān yang selama ini dijadikan rujukan untuk menetapkan hadis/sunnah sebagai sumber hukum dalam Islam. Ayat-ayat tersebut, menurutnya, tidak munasabah dengan dalalah ayat. Misalnya firman Allah dalam surat alBaqarah ayat 129 yang berbunyi; "Ya Tuhan Kami, utuslah untuk mereka sesorang Rasul dari kalangan mereka yang akan membacakan kepada mereka ayat-ayat Engkau dan mengajarkan kepada mereka alKitab (al-Qur'ān) dan al-Hikmah (assunnah) serta mensucikan mereka. Sesungguhnya Engkaulah yang Maha Kuasa lagi Maha Bijaksana". ${ }^{14}$

Kassim Ahmad mengatakan, bahwa Imam Shafi'i (w.204/820M), pengasas teori perundangan Islam klasik, menafsirkan perkataan 'hikmah' dalam ayat di atas dengan sunnah atau hadis. Dalam bukunya, al-Risalah, Imam Syafi'i berkata: "Jadi, Tuhan menyebut kitabNya, yakni al-Qur'ān dan hikmah dan saya telah mendengar daripada mereka yang mahir dalam alQur'ān - mereka yang saya setujui -

\footnotetext{
${ }^{10}$ Ahmad, Hadis Satu Penilaian Semula. Hal. 76

${ }^{11}$ Ahmad, Hadis Satu Penilaian Semula. Hal. 72

12 Ahmad, Hadis Satu Penilaian Semula. Hal. 23

${ }^{13}$ Ahmad, Hadis Satu Penilaian Semula. Hal. 62-63

14 'Q.S. Al-Baqarah'/2: 129.
} 
menyatakan bahwa hikmah itu ialah sunnah Rasulullah. Ini samalah seperti perkataan Tuhan sendiri. Akan tetetapi Tuhan lebih mengetahui. Karena al-Qur'ān disebut, diikut dengan hikmah, kemudian Tuhan menyatakan nikmatNya kepada manusia dengan mengajarkan al-Qur'ān dengan hikmah. Jadi, tidak mungkin hikmah diartikan selain daripada sunnah Rasulullah...". 15

Kassim Ahmad mengatakan, bahwa kita tidak dapat menerima begitu saja tafsiran Imam Syafi'i mengenai perkataan "hikmah". Tidak dapat tidak, kita harus mengajukan pertanyaan apakah ada munasabah penafsiran perkataan 'hikmah' di sini sebagai sunnah? Kassim Ahmad mengatakan, penafsiran ini tidak munasabah. Perhatikan bagaimana Imam Syafi'i, dalam petikan tersebut, bermula dengan mengutip pendapat ahli-ahli yang beliau setujui dan kemudian melompat kepada kepastian bahwa "hikmah" tidak lain adalah sunnah. Kita tahu bahwa tiap-tiap pendapat boleh diperdebatkan, namun tidak demikian untuk kepastian. Kepastian tidak boleh diperdebatkan, melainkan harus diterima. Dalam petikan di atas kita melihat Imam Syafi'i melompat dari pada pendapat kepada kepastian tanpa memberi hujah-hujah yang kokoh untuk membolehkan kita menerima pendapat tersebut sebagai kepastian. Ini satu contoh penghujahan yang longgar yang tidak boleh diterima dalam kaedah saintifik. ${ }^{16}$

Selanjutanya, Kassim Ahmad mengatakan bahwa bila kita mengkaji penggunaan perkataan 'hikmah' dalam al-Qur'ān, jelaslah maksudnya adalah alQur'ān atau ajaran-ajaran al-Qur'ān. Bahkan, Maulana Muhammad Ali dalam tafsirnya menyebut al-hikmah sebagai salah satu nama al-Qur'ān. ${ }^{17}$ Hal ini dapat dilihat, misalnya dalam Q.S. al Imran/3:58, Q.S. Yasin/36:1-2, Q.S. al-Zukhruf/:1-4, Q.S. alQamar/54:5. Demikian juga dengan penggunaan kata 'hakim' dengan maksud "bijaksana" selalu dirujuk kepada Tuhan. Hal ini dapat dilihat, misalnya dalam Q.S. al-Baqarah/2:129 dan Q.S. ash-Shaff/61:1.

Berdasakan keterangan-keterangan al-Qur'ān tersebut, kita dapat menyimpulkan bahwa perkataan 'hikmah' dalam ayat-ayat yang dirujuk oleh Imam Syafi'i dan dalam ayat-ayat lainnya adalah berart al-Qur'ān atau ajaran-ajaran alQur'ān. Tafsiran Syafi'i bahwa 'hikmah” bermakna 'sunnah' atau 'hadis' merupakan satu tafsiran yang subjektif dan sewenang-wenang, dan tidak dapat kita terima. ${ }^{18}$

Demikian juga dengan firman Allah dalam surat al-Najmi ayat 3-4, yaitu; "Dan tiadalah yang diucapkannya itu (al-Qur'ān) menurut kemauan hawa nafsunya. Ucapannya itu tiada lain hanyalah wahyu yang diwahyukan (kepadanya)". 19

Ayat ini menurut, Kassim Ahmad bercerita tentang proses wahyu dan bukan menunjukkan kepada anjuran al-Qur'ān untuk menggesa umat Muhammad SAW mempercayai hadis Nabi SAW, sebagaimana dipahami oleh ahlu al-hadis. Hal ini

\footnotetext{
${ }^{15}$ Ahmad, Hadis Satu Penilaian Semula. Hal. 31

${ }^{16}$ Ahmad, Hadis Satu Penilaian Semula. Hal. 31

${ }^{17}$ Ahmad, Hadis Satu Penilaian Semula. Hal. 32

${ }^{18}$ Ahmad, Hadis Satu Penilaian Semula. Hal. 33

19 'Q.S. Al-Najm' 53/3-4.
} 
sesuai dengan konteks ayat tersebut yang menjelaskan tentang proses wahyu dan bukan kepada percakapan biasa beliau. ${ }^{20}$ Perhatikan konteksnya:

"Demi bintang ketika terbenam. Kawanmu (Muhammad) tidak sesat dan tidak pula keliru. Dan Tiadalah yang diucapkannya itu (al-Qur'ān) menurut kemauan hawa nafsunya. Ucapannya itu tiada lain hanyalah wahyu yang diwahyukan (kepadanya). Yang diajarkan kepadanya oleh (Jibril) yang sangat kuat. Yang mempunyai akal yang cerdas; dan (Jibril itu) menampakkan diri dengan rupa yang asli. Sedang Dia berada di ufuk yang tinggi. Kemudian Dia mendekat, lalu bertambah dekat lagi. Maka jadilah Dia dekat (pada Muhammad sejarak) dua ujung busur panah atau lebih dekat (lagi). Dia menyampaikan kepada hambaNya (Muhammad) apa yang telah Allah wahyukan". ${ }^{21}$

Dengan demikian, menjadi jelas bahwa ayat-ayat ini menunjuk kepada proses wahyu yang disampaikan kepada Nabi Muhammad. Hal itu dibenarkan oleh ahli-ahli tafsir yang masyhur. Dimana dan bagaimana wahyu itu diberikan tidak ada manusia yang mengetahuinya. Akan tetapi, ayat-ayat tersebut jelas merujuk kepada proses wahyu dan bukan kepada percakapan biasa Nabi. Bahwa Muhammad juga seorang manusia biasa telah diterangkan dalam al-Qur'ān dan telah dibuktikan dengan menunjukkan beberapa kesilapan yang telah dilakukannya, demikian juga dalam beberapa buah hadis. $^{22}$

Kassim Ahmad mengatakan bahwa pandangan Fazlul Karim yang mengatakan hadis ialah wahyu tanpa bentuk huruf dan perkataan dibantah oleh ayat al-Qur'ān sendiri yang menegaskan bahwa Nabi Muhammad berpegang kepada kalimah Allah. Jadi, mengikut Nabi Muhammad bermakna berpegang kepada alQur'ān, kepada hadis/sunnah. ${ }^{23}$ dan bukan

Selanjunya, Kassim Ahmad membantah pendapat yang mengatakan bahwa ketaatan kepada rasul sebagai ketaatan kepada Allah dan keingkaran mentaati rasul sebagai keingkaran kepada Allah yang tidak akan dimaafkan. ${ }^{24}$ Ayat-ayat al-Qur'ān yang digunakan oleh ahl al-hadis untuk menyandarkan pendapat mereka, antara lain; Q.S. al-Nisa /4;59, Q.S. al-Hasyr/59:7, dan Q.S. al-Nisa `4:65.

Berdasarkan ayat di atas, menurut Kassim Ahmad, ada dua ide yang dikemukakan oleh ahlu al-hadis. Pertama, Nabi Muhammad harus dipatuhi tanpa syarat, baik dia sebagai rasul atau sebagai pemimpin dan hakim. Kedua, kepatuhan kepada nabi berarti berpegang kepada hadis/sunnah. Dalam ayat pertama, ketaatan kepada rasul berarti ketaatan kepada Tuhan, karena rasul adalah utusan Tuhan yang menyampaikan al-Qur'ān. Al-Qur'ān memaklumi kita bahwa, "satusatunya tugas rasul ialah menyampaikan perutusan." 25 Perhatikan pula, bahwa dalam ayat itu

\footnotetext{
${ }^{20}$ Ahmad, Hadis Satu Penilaian Semula. Hal. 35

21 'Q.S. Al-Najm' 53/1-10.

${ }^{22}$ Ahmad, Hadis Satu Penilaian Semula. Hal. 36

${ }^{23}$ Ahmad, Hadis Satu Penilaian Semula. Hal. 36

${ }^{24}$ Ahmad, Hadis Satu Penilaian Semula. Hal. 36-37

25 'Q.S. Al-Maidah' 5/99.
} 
Tuhan menggunakan perkataan 'rasul' dan tidak 'Muhammad'. Ini jelas menunjukkan bahwa perutusan rasul yang dikehendaki kita taat dan bukan perkataan Muhammad. ${ }^{26}$ Ketaatan kepada rasul berarti ketaatan kepada Tuhan dapat dibuktikan pada firman Allah, misalnya Q.S. Saba`34:46, Q.S. al-Hujurat/49:10, Q.S. Lukman/31:22, dan Q.S. az-Zumar/ 39:54. Ayat-ayat tersebut jelasjelas menunjukkan makna ketaatan kepada rasul, yang membawa makna ketaatan kepada Tuhan. Karena Tuhan tidak datang kepada manusia kecuali melalui rasul-rasul-Nya. ${ }^{27}$

Kassim Ahmad membantah tugas Nabi SAW sebagai penafsir alQur'ān, dan tafsiran beliau diperoleh melalui hadis. Kassim Ahmad menolaknya dengan mengatakan bahwa andaikata keterangan Nabi SAW terhadap hal-hal yang mujmal ini tidak terpelihara dan terjamin dari campur tangan pihak luar, niscaya tidak dapat digunakan lagi nasnas al Qur'ān itu. Dengan begitu akan gugurlah sebahagian besar nash-nash al-Qur'ān yang wajib kita jalankan. Jika demikian, tentu kita tidak dapat mengetahui maksud Allah sebenarnya.",28

Kassim Ahmad mengutip pendapat Mahmud Saedon yang mengatakan, bahwa Nabi Muhammad SAW merinci perkara-perkara yang mujmal atau universal dalam al-Qur'ān, seperti waktu dan rakaat sembahyang dan kadar zakat; Nabi menjelaskan perkara-perkara yang samar dalam al-Qur'ān, seperti waktu imsak; Nabi mengkhususkan perintah-perintah yang umum dalam al-Qur'ān, seperti dalam pembahagian harta pusaka, di mana kononnya, hadis melarang pembahagian kepada anak-anak yang membunuh ibu-bapak; dan Nabi menghadkan atau membataskan perintah-perintah al-Qur'ān, seperti penentuan kaedah melaksanakan hukum potong tangan dan seterusnya. ${ }^{29}$

Dengan demikian jelaslah bahwa apa yang dimaksud oleh ahlu al-hadis di sini ialah tugas nabi sebagai pemimpin yang terkandung dalam konsep ulil amri. Adalah mustahil bagi Nabi Muhammad SAW atau para ahli tafsir untuk menjelaskan dan menafsirkan al-Qur'ān sekaligus secara mutlak, karena al-Qur'ān adalah sebahagian dari ilmu Tuhan yang hanya dapat dicapai sedikit demi sedikit melalui kajiankajian saintifik dan pemikiran rasional dalam rentang waktu yang panjang. Para ahli tafsir periode klasik, periode pertengahan hingga zaman modern telah membuktikan perkara ini. ${ }^{30}$ Hal ini diterangkan dalam al-Qur'ān, misalnya dalam surat alImran/3:7, surat al-Qiyamah/75:16-19 dan surat al-Rahman/55:1-2. Dalam surat ali Imran ayat 7, Allah berfirman; "Dia-lah yang menurunkan al kitab (al-Qur'ān) kepada kamu di antara (isi) nya ada ayat-ayat yang muhkamaat. Itulah pokok-pokok isi alQur'ān dan yang lain (ayat-ayat) mutasyaabihaat. Adapun orang-orang yang dalam hatinya condong kepada kesesatan, maka mereka mengikuti sebahagian ayatayat yang mutasyaabihaat daripadanya untuk menimbulkan fitnah untuk mencari-

\footnotetext{
${ }^{26}$ Ahmad, Hadis Satu Penilaian Semula. Hal. 37-38

${ }^{27}$ Ahmad, Hadis Satu Penilaian Semula. Hal. 38

${ }^{28}$ Ahmad, Hadis Satu Penilaian Semula. Hal. 43

29 Ahmad, Hadis Satu Penilaian Semula. Hal. 43

${ }^{30}$ Ahmad, Hadis Satu Penilaian Semula. Hal. 44
} 
cari ta'wilnya, padahal tidak ada yang mengetahui ta'wilnya melainkan Allah. Dan orang-orang yang mendalam ilmunya berkata: "Kami beriman kepada ayat-ayat yang mutasyaabihaat, semuanya itu dari sisi Tuhan kami, dan tidak dapat mengambil pelajaran (daripadanya) melainkan orang-orang yang berakal". 31

Kassim Ahmad mengatakan, bahwa dalam al-Qur'ān dijelaskan tentang keadaan orang-orang Arab sebelum diutus Nabi Muhammad SAW yang sudah mengamalkan shalat, dan wahyu-wahyu al-Qur'ān yang paling awal sudah menyebut shalat dan zakat. Ini membuktikan bahwa ibadah-ibadah ini sudah terkenal di kalangan orang-orang Arab. ${ }^{32}$ Hal ini dapat dilihat dalam al-Qur'ān, misalnya dalam surat alMuzammil/73:20 dan surat al-Anfal/8:35.

Ibn Ishaq mencatat dalam sirahnya bahwa sebelum Nabi Muhammad SAW diangkat menjadi rasul, beliau mengunjungi Gua Hira' setiap tahun dalam bulan Ramadhan untuk menyendiri/berkhalwat dengan melakukan shalat. Ibn Ishaq juga mencatat bahwa sebelum Nabi israk dan mikraj, Nabi Muhammad SAW melaksanakan shalat di rumah Ummu Hani. Kesemua fakta ini menafikan laporanlaporan hadis yang menyatakan bahwa ibadah shalat diperintahkan oleh Tuhan kepada Nabi Muhammad pada malam israk dan mikraj. ${ }^{33}$

Dengan demikian, kaedah-kaedah shalat (waktu, rakaat dan gerak-geriknya), yang dikerjakan oleh umat Islam sekarang, pada dasarnya berasal dari amalan Nabi Ibrahim dan pengikut-pengikutnya. Dan kaedah-kaedah ini diturunkan dari satu generasi ke generasi berikutnya hingga kepada Nabi Muhammad SAW. Hal ini dapat dilihat dalam al-Qur'ān, misalnya tentang jumlah waktu shalat yang diwajibkan (Q.S 11:114, Q.S 17:78, Q.S 24:58, Q.S 2:238, Q.S 30:17-18 dan Q.S 20:130); perbuatan rukuk dan sujud (Q.S 22:77); qasar shalat (Q.S 4:101); bentuk yang boleh disesuaikan dalam keadaan perang dan keadaan luar biasa (Q.S 2:239); berpakaian bersih (Q.S 7:31); cara bacaan yang sederhana (Q.S 17:110); jangan menyerukan selain Allah dalam sembahyang (Q.S 72:18) dan cara-cara berwudu' (Q.S 5:6 dan Q.S 4:43). Walaupun diakui dalam ayat tersebut tidak dijelaskan secara rinci tentang gerakan shalat, namun prinsip umum dari shalat sudah disebutkan. Al-Qur'ān mengajarkan kita supaya jangan mempertikaikan bentuk dan kaedah. Bentuk dan kaedah tidak begitu penting jika dibandingkan dengan tujuan, yaitu kebaikan dan kejujuran untuk melakukan kebaikan. ${ }^{34}$

Kebaikan bukanlah berpaling ke Timur atau ke Barat. Kebaikan ialah beriman kepada Tuhan, hari kiamat, malaikat-malaikat, kitabkitab dan nabi-nabi; dan mendermakan uang yang kita sayangi kepada kaum keluarga, anak-anak yatim, orang-orang miskin, orang-orang asing, pengemis-pengemis, dan membebaskan hamba-abdi, dan melaksanakan shalat dan zakat, dan menunaikan janji-janji yang

\footnotetext{
31 'Q.S. Al-Imran' 3/7.

${ }^{32}$ Ahmad, Hadis Satu Penilaian Semula. Hal. 45

${ }^{33}$ Ahmad, Hadis Satu Penilaian Semula. Hal. 45

${ }^{34}$ Ahmad, Hadis Satu Penilaian Semula. Hal. 46
} 
dibuat, dan tetap teguh menghadapi bencana, kesusahan dan peperangan. ${ }^{35}$ Dalam alQur'ān surat al-Ma'un, ayat 1-7 Allah berfiman; "Tahukah kamu (orang) yang mendustakan agama? Itulah orang yang menghardik anak yatim, Dan tidak menganjurkan memberi makan orang miskin. Maka kecelakaanlah bagi orang-orang yang shalat. Yaitu, orangorang yang lalai dari shalatnya. Orang-orang yang berbuat riya. Dan enggan (menolong dengan) barang berguna."36 Dan firman Allah dalam surat al-Ahzab ayat 21, berbunyi; "Sesungguhnya telah ada pada (diri) Rasulullah itu suri teladan yang baik bagimu (yaitu) bagi orang yang mengharap (rahmat) Allah dan (kedatangan) hari kiamat dan dia banyak menyebut Allah". 37

Menurut Kassim Ahmad, ungkapan uswatun hasanah (contoh yang baik) dalam ayat itu merujuk kepada pegangan, pendirian dan perjuangan dan bukan kepada gerak gerik dan kelakuan. ${ }^{38}$ Dan ini dapat dibuktikan dengan penggunaan ungkapan tersebut sebanyak dua kali untuk Nabi Ibrahim yang memegang teguh agama tauhid. Hal ini dapat dilihat dalam al-Qur'ān surat al-Mumtahanah/60 ayat 4 dan 6. Dalam ayat ini dijelaskan makna sebenarnya dari kata "uswatun hasanah". Dan sekaligus contoh bagaimana al-Qur'ān menafsirkan dirinya sendiri. ${ }^{39}$

Kasim Ahmad selanjutnya mengatakan, bahwa adalah tidak munasabah dan mustahil bagi Tuhan menyuruh umat Islam mengikuti segala gerak gerik dan tingkah laku nabi, karena gerak gerik dan tingkah laku seseorang ditentukan oleh faktorfaktor seperti kebudayaan, pendidikan, waktu dan tempat serta perbuatan pribadi. Cara nabi makan dan berpakaian adalah mengikut kebudayaan Arab. Kandungan Islam dalam kasus ini hanya terletak pada makanan yang dihalalkan oleh Islam dan cara berpakaian yang sopan menutup aurat. Sekiranya nabi lahir dari kalangan bangsa Cina, tentu beliau akan makan dan berpakaian mengikut kebudayaan Cina. Gerakgerik dan kelakuan ini sama sekali tidak ada kaitannya dengan akidah, pegangan, pendirian dan perjuangan seseorang. Sebenarnya sunnah Nabi itu adalah al-Qur'ān. Nabi berpegang teguh kepada al-Qur'ān dan mengikut perintah-perintah Tuhan. Dengan demikian, mengikut sunnah Nabi berarti mengikut al-Qur`an. ${ }^{40}$

Al-Qur'ān sudah lengkap, sempurna dan terperinci. Bila Tuhan sengaja meninggalkan sesuatu perkara dalam al-Qur'ān, seperti rincian shalat, tentu ada hikmahnya. Sebagaimana firman Allah dalam al-Maidah/5:101.

"Hai orang-orang yang beriman janganlah kamu menanyakan (kepada nabimu) hal-hal yang jika diterangkan kepadamu, niscaya menyusahkan kamu dan jika kamu menanyakan diwaktu al-Qur'ān itu sedang diturunkan, niscaya akan diterangkan kepadamu. Allah memaafkan kamu tentang hal-hal itu. Allah maha pengampun lagi maha penyayang." 41

\footnotetext{
${ }^{35}$ Ahmad, Hadis Satu Penilaian Semula. Hal. 46

36 'Q.S. Al-Ma'un' 107/1-7.

37 'Q. S.Al-Ahzab’ 33/21.

${ }^{38}$ Ahmad, Hadis Satu Penilaian Semula. Hal. 48

${ }^{39}$ Ahmad, Hadis Satu Penilaian Semula. Hal. 49

${ }^{40}$ Ahmad, Hadis Satu Penilaian Semula. Hal. 49

41 'Q.S. Al-Maidah' 5/101.
} 
Ayat di atas menjelaskan, bahwa yang perlu dipatuhi oleh orangorang mukmin tanpa syarat adalah al-Qur'ān. Jadi, jangan kita bertanya tentang hal-hal yang sengaja ditinggalkan oleh Tuhan dalam wahyu-wahyuNya. Sebab, jika hal itu disebutkan dalam al Qur'ān maka mestilah orang mukmin mematuhinya. Dan terhadap hal-hal yang tidak disebutkan Tuhan dalam al-Qur'ān, maka itu berarti untuk membolehkan manusia bertindak mengikut kehendak dan keperluan mereka masing-masing. Dengan demikian jelas, ayat ini menolak buku-buku lain selain dari al-Qur'ān, sebagai sumber undang-undang. Artinya, menempatkan hadis sebagai sumber hukum di samping alQur'ān, jelas bertentangan dengan ayat ini. Dan kalau itu terjadi, berarti kita termasuk orang-orang yang disifatkan Tuhan sebagai orang-orang musyrik. $^{42}$

Kassim Ahmad mengatakan, salah satu khurafat yang masuk kedalam hadis ialah mitos Imam Mahdi yang konon akan muncul di akhir zaman untuk membela dan menyelamatkan umat Islam dan manusia dari pemerintahan yang zalim. Dan mitos orang-orang Islam yang masuk sorga hanya dengan mengucap dua kalimah syahadat disaat sakratul maut. Kedua-dua hadis ini jelas bertentangan dengan ajaran al-Qur'ān dan hukum akal. Al-Qur'ān senantiasa mendorong orang-orang mukmin untuk berjuang di jalan Allah dengan berbuat baik setiap saat tanpa menunggu kedatangan Imam Mahdi. Hukum akal juga tidak bisa menerima bahwa sesuatu perubahan akan terjadi pada masyarakat Islam, kecuali masyarakat Islam sendiri yang melakukan perjuangan. ${ }^{43}$

Oleh karena itu, Kassim Ahmad menekankan perlunya peninjauan ulang terhadap semua hadis dan tamaddun Islam. Umat Islam jauh terkebelakang bila dibandingkan dengan Eropa, Jepang, Amerika dan Rusia, karena umat Islam berpegang kepada hadis. ${ }^{44}$ Bahkan, Kassim Ahmad menuduh hadis/sunnah sebagai penyebab Islam mundur dan terzalimi. ${ }^{45}$ Dan hadis sebagai penyebab kekeliruan dan perpecahan umat Islam. ${ }^{46}$

\section{Analisis terhadap Pemikiran Inkar Sunnah Kassim Ahmad}

Pemikiran dan argumentasi yang dikemukakan Kassim Ahmad, dinilai kontroversial dengan alasan sebagai berikut:

a. Kalau benar Kassim Ahmad berpegang dengan al-Qur'ān semata, tentu dia tidak menitik beratkan pengumpulan hadis dan al-Qur'ān dalam bentuk tulisan karena tidak ada dalam al-Qur'ān suruhan supaya al-Qur'ān dan hadis ditulis. Yang mengeluarkan arahan supaya ditulis adalah Rasulullah dan tiaptiap yang diperintah oleh Rasulullah disebut hadis. Sementara Kassim menolak hadis.

\footnotetext{
${ }^{42}$ Ahmad, Hadis Satu Penilaian Semula. Hal. 54-55

${ }^{43}$ Ahmad, Hadis Satu Penilaian Semula. Hal. 77

${ }^{44}$ Ahmad, Hadis Satu Penilaian Semula. Hal 13-14

${ }^{45}$ Ahmad, Hadis Satu Penilaian Semula. Hal. 23

${ }^{46}$ Ahmad, Hadis Satu Penilaian Semula. Hal. 80
} 
b. Andaikata Kassim Ahmad dapat memahami al-Qur'ān secara baik, maka dia akan menjumpai banyak ayat dalam al-Qur'ān yang menegaskan bahwa hakikatnya hadis tersebut adalah juga wahyu dari Allah. Di antara ayat-ayat dimaksud, yaitu; Q.S al-Tahrim/66:3; Q.S al-Hasyar/59:5; Q.S Yunus/10:15; Q.S al Najmi/53:23;Q.S al-A raf/7:204; Q.S al-Nisa/4:3; Q.S al-Qiyamah/ 75:18-19; Q.S al-Baqarah/2:144; Q.S ali-Imran/3:124; Q.S al-Hajj/22:37; Q.S al-Isra /17:60; Q.S al-Najmi/53:10; Q.S al-Nisa`4:59; Q.S; al-Nahl/16:44; Q.S al-Hasyar/59:7. Ayat ayat tersebut membuktikan bahwa al-Qur'ān dan alsunnah tidak dapat dipisahkan. Karena apa yang disebut dalam al-Qur'ān, operasio-nalisasinya dijelaskan dalam hadis atau sunnah.

c. Sejarah memang mencatat bahwa Islam telah mengalami kemunduran, namun hadis sama sekali tidak diidentifikasi sebagai penyebab kemunduran itu. Perpecahan internal di kalangan umat Islamlah yang menjadi penyebabnya. Bahkan bukti sejarah menunjukkan bahwa hadis yang berkembang bersamaan dengan masa kemajuan Islam periode klasik, turut andil dalam mendorong kemajuan Islam, di antaranya dengan seruannya untuk menuntut ilmu.

d. Argumentasi Kassim Ahmad bahwa hadis Nabi Muhammad SAW lahir lama setelah Nabi Muhammad SAW wafat, tepatnya pada zaman al-tabi'in dan atbau al-tabi'in adalah sangat tidak berdasar. Sejak masa Islam paling awal hadis Nabi SAW telah lahir dan mendapat perhatian luas dari kalangan sahabat, sebagaimana yang ditunjukkan oleh Ibn Abbas (w.69H/689M) dan Ibn Amr bin al-Ash (w.65H/685M) yang dikenal sebagai sahabat yang rajin mencatat hadis Nabi Muhammad SAW. Meskipun pentadwinan atau pengkodifikasian hadis Nabi Muhammad SAW baru dilakukan pada masa khalifah Umar bin Abdul Azis (w.101H/720M), namun pencatatannya telah dilakukan jauh sebelumnya. Pernyataan bahwa hadis Nabi Muhammad SAW adalah sesuatu yang diadaadakan, dalam hal ini, sama sekali tidak bisa diterima.

e. Tentang pernyataan bahwa dalam kitab-kitab hadis standar terdapat hadishadis yang berkualitas dha'if atau bahkan diduga maudhu' tidaklah dibantah. Namun, hal itu bukan berarti bahwa seluruh hadis yang ada di dalamnya berkualitas demikian sehingga harus ditolak kehujjahannya. Begitu pula dengan hadis yang secara lahir tampak bertentangan dengan al-Qur'ān, logika, sejarah atau denga hadis-hadis lain tidak bisa dengan serta merta ditolak kehujjahannya. Karena untuk menyelesaikan itu telah ada suatu cabang ilmu hadis yang dikenal dengan Ilmu Mukhtalif al-Hadis atau Ma'rifah Mukhtalif al-Hadis.

f. Adapun yang terkait dengan tuduhan kepada Imam Syafi'I yang dikatakan telah merekayasa hadis untuk dijadikan sumber hukum. Sebagaimana dikatakan Kassim Ahmad, bahwa orang-orang Islam mesti berpegang dengan al-Qur'ān dan al-hadis mengikut ajaran fiqh. Teori fiqh itu sendiri digagas 
oleh Imam Syafi'i dua ratus tahun sesudah meninggalnya Rasulullah SAW. ${ }^{47}$ Tuduhan ini tidak mempunyai dasar yang jelas. Mungkin bagi orang awam yang tidak punya pengetahuan dapat mempercayai pendapat Kassim Ahmad. Imam Syafi'i bukan pendiri teori fiqh. Yang benar adalah Imam Syafi'i pendiri salah satu mazhab fiqh. Tetapi bagi Kassim Ahmad tidak ada mazhab fiqh lain, selain Syafi'i. Seolah-olah seluruh kaum muslimin di dunia ini mengikut mazhab Syafi'i. Kassim Ahmad tidak menyentuh nama-nama mazhab fiqh lain, seperti; Abu Hanifah (80-150H); Imam Malik (97-179H); Ahmad ibn Hambal (164-241H) dan Daud Zahiri (200-279H). Ini menunjukkan bahwa Kassim Ahmad tidak punya pengetahuan tentang mazhab-mazhab tersebut.

g. Pandangan Kassim Ahmad yang menyebutkan bahwa taat kepada Nabi hanya terbatas semasa beliau hidup. Setelah Nabi wafat, maka tidak boleh dipanggil Nabi dan tiada ketaatan kepada orang yang telah meninggal. ${ }^{48}$ Sadar atau tidak, pemikiran Kassim Ahmad ini telah terpengaruh oleh agama Bahài. Bahkan lebih sesat dari agama tersebut. Sebab, dalam agama Baha`i masih mengakui ada satu rangkaian Nabi yang disebut Mazharullah. Apa bedanya meninggal dengan berjauhan. Bagi seorang muslim taat kepada Nabi tidak terbatas hanya seketika beliau masih hidup atau sesudah beliau meninggal. Dan juga tidak terbatas, baik berada di sampingnya atau berada di tempat lain. Tidak ada bedanya taat kepada Nabi waktu beliau masih hidup dengan ketaatan kepadanya sesudah beliau meninggal. Karena pada hakikatnya kewafatan itu hanya sejenis berjauhan. Sebab risalah al-Qur'ān dan al-hadis itu abadi dan tidak terikat oleh waktu dan tempat.

h. Kassim Ahmad dan kelompoknya menyebut mereka sebagai Jama'ah Ahl alQur'ān Malaysia (JAM). Penggunaan istilah ahl al-Qur'ān, jelas sangat janggal kalau digunakan bukan pada tempatnya. Dalam sejarah pemikiran Islam terdapat dua golongan yang dikenal dengan nama ahl al-hadis dan ahl alra`yu. Mazhab Hanafi dikenal sebagai ahl al-ra'yu dan mazhab Maliki sebagai ahl al-hadis. Sementara mazhab Syafi'I ialah "penyesuaian" dari dua mazhab itu. Tidak terdapat istilah ahl al-Qur'ān sebagaimana dalam konsep Kassim Ahmad, yaitu golongan orang yang berpegang kepada alQur`an saja dan menolak hadis. Ahl al-ra yu tidak menolak hadis. Ahl al-Qur'ān dalam bahasa sehari dipahami sebagai orang yang menghafal al-Qur'ān, menulis atau membaca al-Qur'ān untuk tujuan ibadat. Kassim Ahmad telah mengelabui masyarakat dengan membuat istilah sendiri yang tidak pernah digunakan oleh para ilmuan Islam sepanjang sejarah.

i. Kassim Ahmad mengatakan, jika hadis menafsir atau memperjelas al-Qur'ān, maka berarti al-Qur'ān tidak jelas dan tidak lengkap. Itu tidak benar, sebab alQur'ān lengkap dan sudah jelas dan tidak memerlukan hadis atau kitab-kitab

\footnotetext{
${ }^{47}$ Ahmad, Hadis Satu Penilaian Semula. Hal. 11

${ }^{48}$ Ahmad, Hadis Satu Penilaian Semula. Hal. 13
} 
lainnya. ${ }^{49}$ Memang betul al-Qur'ān itu jelas dan lengkap, karena di dalamnya juga mengandung perintah untuk mengikuti perintah Nabi Muhammad sebagai Rasulullah, seperti firmanNya, "Taatilah Allah dan taatilah RasulNya...", dan firmanNya, "Dan Kami turunkan kepadamu (Muhammad) alQur'ān agar kamu menerangkan kepada umat manusia apa yang telah diturunkan kepada mereka". Tanpa dua ayat seperti contoh di atas, maka alQur'ān menjadi tidak lengkap. Tegasnya al-Qur'ān itu lengkap, karena dilengkapkan dengan ayat-ayat yang menyuruh kaum muslimin untuk mengikuti Rasul sebagai penjelas isi al-Qur'ān. Penjelasan itu diistilahkan dengan hadis/sunnah. Ayat-ayat seperti contoh di atas sangatlah jelas membuktikan bahwa hadis atau sunnah dalam perkara agama adalah wahyu dari Allah. Taat kepada Rasul berarti ikut al-Qur'ān, meninggalkan hadis/ sunnah berarti mengingkari al-Qur'ān. Ayat-ayat seperti ini sangat jelas tujuannya bagi orang-orang yang menguasai bahasa Arab dan Ulum alQư'ān.

j. Tuduhan Kassim Ahmad terhadap hadis/sunnah sebagai penyebab Islam mundur dan terzalimi. ${ }^{50}$ Dan hadis sebagai penyebab kekeliruan dan perpecahan umat Islam. ${ }^{51}$ Ini adalah suatu bentuk kekeliruan yang sangat mendasar dalam memahami al-Qur'ān. Bukankah, al-Qur'ān sendiri yang menyuruh kita mengikut hadis? Membuang hadis atau sunnah, berarti membuang al-Qur'ān. Jadi sebenarnya Kassim Ahmad membuang al-Qur'ān, apabila dia membuang hadis/sunnah. Ada konflik batin yang berkecamuk dalam dirinya dan dia mengajak orang lain untuk ikut sakit.

Dari segi logika, al-Qur'ān memberitahu kita bahwa Allah SWT telah menurunkan al-Qur'ān kepada Rasulullah SAW untuk diterangkan pula kepada manusia. Dan penerangan ini juga merupakan wahyu yang wajib dituruti. Seseorang tidak dikatakan sebagai taat sekiranya dia hanya patuh kepada ayat al-Qur'ān dengan tidak berpegang kepada orang yang menerangkannya karena penerangan sampai kapanpun tidak dapat dipisahkan daripada orang yang menerangkannya. Sekiranya dia beramal dengan al-Qur'ān seperti yang diterangkan oleh Rasulullah SAW, maka dia telah taat kepada Allah SWT melalui ayat al-Qur'ān dan taat kepada Rasulullah SAW adalah melalui penerangannya. Sekiranya dia mengabaikan penerangan Rasulullah SAW, maka dia telah berdosa kepada Allah SWT karena tidak beramal sebagaimana yang telah diperintahkan Allah SWT.

Dengan demikian, gerakan anti hadis pimpinan Kassim Ahmad, secara tidak langsung boleh dimasukkan kedalam golongan kebatinan, karena golongan ini adalah percikan dari agama Baha`i. Adapun bukti, gerakan ini terpengaruh dengan Baha`i, yaitu; pertama; pendapat mereka yang mengatakan bahwa ajaran Nabi Muhammad

\footnotetext{
${ }^{49}$ Ahmad, Hadis Satu Penilaian Semula. Hal. 12

${ }^{50}$ Ahmad, Hadis Satu Penilaian Semula. Hal. 23

${ }^{51}$ Ahmad, Hadis Satu Penilaian Semula. Hal. 80
} 
hanya sesuai untuk zaman saja, kedua; pengakuan mu'jizat Kod 1952. Mu'jizat "Kod 19" berasal dari agama Baha i, pengasas pertamanya adalah Sayyid Ali Muhammad Syairazi yang terpengaruh oleh Al-Ihsa`i Syekh Thariqat Syaikhiyah dan Kazim alRasti penganut paham kedatangan Imam Mahdi dan "Bab" bagi kedatangannya. Sayyid Ali Muhammad Syairazi mendapat kasaf bahwa dirinya adalah Imam Mahdi yang ditungutunggu, kemudian memperokla-mirkan dirinya "Bab" (pintu) bagi kedatangan Imam Mahdi yang dikatakannya tidak meninggal tetapi bersembunyi sejak tahun $260 \mathrm{H}$.

Dahulu Kassim Ahmad pernah menyampaikan sajak kontroversial yang berjudul Sidang Roh. Kini beliau menyebarkan buku "Hadis Satu Penilaian Semula" yang juga kontroversial. Jika demikian, Kassim Ahmad sekarang adalah Kassim Ahmad yang dulu juga yang suka memunculkan issu kontroversi dan suka dapat perhatian umum.

\section{KESIMPULAN}

Aliran inkar sunnah pimpinan Kassim Ahmad termasuk golongan sesat. Sebab, aliran ini telah menolak hadis shahih sebagai sumber hukum Islam, menghina Nabi Muhammad sebagai Rasulullah, serta memutarbalikkan pengertian ayat-ayat alQur'ān sesuai dengan keinginan mereka. Argumentasi-argumentasi yang dikemukakan oleh Kassim Ahmad dalam menolak hadis adalah keliru. Kekeliruan tersebut, diidentifikasi sebagai akibat kedangkalan mereka dalam memahami Islam dan ajarannya secara holistik. Penekanan secara parsial dan tidak seimbang terhadap beberapa aspek hadis, terurtama aspek ontologis, epistimologis dan historis oleh kelompok ini menjadi sebab munculnya sikap penolakan terhadap kehujjahan hadis. Sosialisasi ajaran inkar sunnah di Malaysia dilakukan dengan berbagai cara, yaitu; menerbitkan Risalah lqra', memuat artikel di media cetak dan internet, diskusi, forum-forum ilmiyah, ceramahceramah dan sebagainya.

\section{DAFTAR PUSTAKA}

Abu Zaky Fadhal, Sidang Roh, Kassim Ahmad, Mengajak Kita Memperhitungkan Kembali Hidup Kita (Kuala Lumpur: Dewan Bahasa, 1966)

Ahmad, Kassim, Biodata Kassim Ahmad (Kuala Lumpur: Bernama Library Information Servis, 1986)

$\longrightarrow$, Hadis Satu Penilaian Semula (Kuala Lumpur: Media Intelek, 1986) Al-Siba`i, Musthafa, Al-Sunnah Wa Makanatuhu Fi Tasyri' Al-Islami (Beirut: al-

${ }^{52}$ Mu'jizat Kod 19 adalah teori yang membuktikan dan memperkuat dakwaan bahwa alQur`an itu dari Allah dengan menilai tiap-tiap huruf menurut kaedah yang disebut hisab jummal atau nilai abjad. Dengan teori ini pula mereka dapat menetapkan tarikh kiamat. Teori ini ditemukan perrtama kali oleh Sayyid Ali Muhammad Syirazi dan Rasyad Khalifa. 
Maktabah al-Islami, 1978)

Azam, Abdurrahman, Keagungan Nabi Muhammad SAW: Kepahlawanan Dan Keindahan Kehidupan Rasulullah (Jakarta: CV Pedoman Ilmu Jaya, 1982)

Hakim, Muhammad Thahir, As-Sunnah Fi Muwajahah Al-Abathil (Jakarta: Granada, 1984)

'Q. S.Al-Ahzab'

'Q.S. Al-Baqarah'

'Q.S. Al-Imran'

'Q.S. Al-Ma'un'

'Q.S. Al-Maidah'

'Q.S. Al-Najm'

Ranuwijaya, Utang, Ilmu Hadis (Jakarta: Gaya Media Pratama, 1996)

Yaqub, Ali Mustafa, Kritik Hadis (Jakarta: Pustaka Firdaus, 1995) 